\title{
"Ceria"'
}

Jurnal Program Studi Pendidikan Anak Usia Dini

ISSN 2301-9905

Volume 10, No 2 Januari 2022

Fakultas Keguruan dan Ilmu Pendidikan - Universitas Muhammadiyah Tangerang

\section{UPAYA MENINGKATKAN KEMAMPUAN MENGENAL KONSEP BILANGAN MELALUI MEDIA SUMPIT ANGKASA PADA ANAK USIA 4 - 5 TAHUN DI TK KHOIRUNNISA KECAMATAN CIKUPA KABUPATEN TANGERANG}

\author{
${ }^{1}$ Titi Rachmi, ${ }^{2}$ Vina Oktavioni \\ ${ }^{1,2}$ Program Studi Pendidikan Guru Pendidikan Anak Usia Dini, Fakultas Keguruan Dan \\ Ilmu Pendidikan, Universitas Muhammadiyah Tangerang \\ Email : ${ }^{1}$ titirachmi@gmail.com, ${ }^{2}$ vinahumaedi@gmail.com
}

\begin{abstract}
ABSTRAK
Penelitian ini bertujuan untuk mengetahui kemampuan mengenal konsep bilangan melalui media sumpit angkasa pada anak usia 4-5 tahun di TK Khoirunnisa Kecamatan Cikupa Kabupaten Tangerang. Metode yang digunakan adalah penelitian tindakan kelas (PTK) model penelitian Kurt Lewin yang dilakukan sebanyak tiga (3) siklus. Prosedur penelitian ini terdiri dari 4 tahapan yaitu: Perencanaan tindakan, pelaksanaan tindakan, observasi dan refleksi. Metode pengumpulan data yang digunakan dalam penelitian ini adalah observasi,waawancara dan dokumentasi. Subjek penelitian ini adalah anak usia 4- 5 tahun yang mengalami masalah dalam mengenal konsep bilangan, seperti membilang, mengurutkan bilangan,membandingkan lambang bilangan, menulis lambang bilangan, menghubungkan lambang bilangan dengan benda dan menunjukan lambang bilangan. Hasil penelitian menunjukan bahwa terjadi peningkatan kemampuan mengenal konsep bilangan melalui media sumpi angkasa. Kemampuan mengenal konsep bilangan pada siklus I mencapai 53\%, pada siklus II meningkat mencapai $73 \%$ dan pada siklus III meningkat menjadi 93\%. Dengan demikian dapat disimpulkan bahwa media pembelajaran yang menarik memiliki dan inovatif dapat meningkatkan kemampuan mengenal konsep bilangan melalui media sumpit angkasa. Dengan demikian terbukti bahwa melalui media sumpit angkasa dapat meningkatkan kemampuan mengenal konsep bilangan pada anak usia 4-5 tahun di TK Khoirunnisa Kecamatan Cikupa Kabupaten Tangerang.
\end{abstract}

Kata Kunci : konsep bilangan, media, sumpit angkasa 


\section{Pengantar}

Anak usia dini adalah makhluk individu kecil yang memiliki jenjang usia dari nol sampai enam tahun, Anak usia dini merupakan manusia unik, polos dan suka dengan hal-hal baru serta memiliki pola pikir yang berbeda dengan orang dewasa. Mereka nampak aktif, antusias dan memiliki rasa ingin tahu yang tinggi terhadap sesuatu yang ada disekitarnya. Pola pertumbuhan dan perkembangannya sangat pesat sehingga dapat dengan mudah diberikan stimulasi untuk perkembangan kecerdasannya.

Maka dari itu perlunya pendidikan sejak usia dini yang didasarkan pada UndangUndang Nomor 20 Tahun 2003 tentang Sistem Pendidikan Nasional, yang menyatakan bahwa pendidikan anak usia dini adalah salah satu upaya pembinaan yang ditujukan untuk anak sejak lahir sampai dengan enam tahun yang dilakukan melalui pemberian rangsangan pendidikan untuk membantu pertumbuhan dan perkembangan jasmani dan rohani agar anak memiliki kesiapan dalam memasuki jenjang pendidikan lebih lanjut. dirancang dan disesuaikan dengan tahapan perkembangan dan karakteristik belajar anak.

Sederhananya konsep PAUD adalah konsep pendidikan yang ingin menawarkan kepada masyarakat akan pentingnya pendidikan karakteristik perilaku dan kecerdasan anak usia dini serta pemberian rangsangan pendidikan untuk membantu pertumbuhan dan perkembangan jasmani serta rohani. PAUD juga merupakan pendidikan fundamental dalam memberikan kerangka dasar terbentuk dan berkembangnya dasardasar pengetahuan, sikap dan keterampilan pada anak usia dini.

Salah satunya perkembangan kognitif, perkembangan ini merupakan Salah satu aspek perkembangan yang dikembangkan di Taman Kanak kanak . Secara umum perkembangan konitif adalah perubahan dalam pemikiran, kecerdasan dan bahasa anak. Proses perkembangan kognitif mampu membuat anak mengingat, membayangkan bagaimana cara memecahkan masalah dan menyusun strategi kreatif. Seperti yang diungkapkan Pudjianti (2016) bahwa kognitif diartikan sebagai kemampuan belajar untuk mempelajari keterampilan atau konsep baru, kemampuan untuk memahami apa yang terjadi dilingkungan sekitar. 
Lingkup perkembangan kognitif mencakup belajar dan pemecahan masalah, berpikir logis, serta berpikir simbolik. Perkembangan kognitif pada anak usia dini disajikan dan dikemas dalam pembelajaran tematik yang berarti ilmu tentang bilangan-bilangan ,hubungan antar bilangan dan prosedur operasional yang digunakan dalam penyelesaian persoalan mengenai bilangan. Salah satunya dengan mengenal konsep bilangan dan berhitung.

Bilangan adalah suatu konsep matematika yang digunakan untuk pencacahan dan pengukuran. Sugianto (2012, hlm. 11) bahwa konsep bilangan adalah "pengenalan bilangan dengan menggunakan benda-benda kongkret." Maka diperlukan adanya simbol ataupun lambang yang digunakan untuk mewakili suatu bilangan yang disebut sebagai angka atau lambang bilangan. Angka atau lambang bilangan terdiri dari 0,1,2,3,4,5,6,7,8,9,10. Pengenalan lambang bilangan pada anak dapat dimulai dari pengenalan bilangan kemudian mengajarkan anak tentang pengertian lambang bilangan atau angka. Hal tersebut dapat dilakukan dengan menggunakan berbagai macam benda yang menarik yang ada disekitar anak dan melalui sebuah permainan untuk mendorong anak memahami lambang bilangan dengan baik.

Namun permasalahan yang dihadapi sekarang berdasarkan hasil observasi pada bulan Maret 2021 kepada siswa siswi pada kelas A ( Al Qoyyum) dengan jumlah siswa 15 dengan perbandingan 7 siswa laki-laki dan 8 siswa perempuan di TK Khoirunnisa Kecamatan Cikupa Kabupaten Tangerang anak - anak menunjukkan kurangnya pemahaman dan kekeliruannya akan pengenalan bentuk bilangan, yang ditandai dengan kelirunya menyebutkan lambang bilangan 6 dan 9. Ketika pembelajaran anak diminta menunjukan angka 6 namun anak tersebut kebingungan dan malah menunjuk angka 9 .

Media pembelajaran pada tingkat TK sangat diperlukan saat mengajar, karena dunia anak merupakan dunia bermain, maka dari itu pembelajaran yang ada di TK seharusnya diarahkan dengan cara bermain sambil belajar yang dikemas dengan menarik. Dalam mengembangkan kemampuan mengenalkan konsep bilangan pada anak-anak dapat dilakukan dengan berbagai hal, salah satunya dengan menggunakan media sumpit angkasa untuk mengenalkan angka 1 sampai 10. Sumpit Angkasa adalah 
salah satu media pembelajaran visual dimana media ini bisa digunakan oleh 2 sampai 3 anak. Sumpit angkasa merupakan media pembelajaran yang menstimulasi pengenalan konsep bilangan pada anak usia dini. Melalui kegiatan bermain sumpit angkasa anak dapat bermain sambil belajar mengenal konsep bilangan yaitu 1,2,3,4,5,6,7,8,9,10 secara langsung yang dimulai pada jenjang mengetahui, memahami, dan menerapkan pada kegiatan sehari-hari.

Kemampuan merupakan potensi yang ada pada diri individu sejak lahir dan merupakan kesanggupan individu dalam melaksanakan berbagai tugasnya baik secara mental ataupun fisik. Potensi ini bisa di asah atau distimulus, jadi setiap individu memiliki kemampuan yang berbeda-beda sesuia dengan pembiasaan dan latihan yang mereka lakukan. Kemampuan juga merupakan bakat alami individu yang diberikan oleh sang pencipta sebagai bekal awal individu tersebut menjalani kehidupannya.

Bilangan adalah bentuk yang berupa angka yang sering kita temui dalam pembelajaran matematika yang berfungsi menunjukan banyaknya suatu himpunan. Anak usia dini menetapkan nilai bilangan pada benda yang mereka hitung. Seperti, menghitung jumlah pensil yang akan mereka gunakan, dan menghitung jumlah anak tangga yang mereka naiki setiap hari. Menurut Sriningsih dalam (Ulum, 2014, hlm. 14) bilangan adalah suatu konsep matematika yang terdiri dari nama, urutan, lambang dan jumlah. Untuk menyatakan suatu jumlah dapat dituliskan dengan lambang bilangan yang disebut angka. Sebagaimana yang dijelaskan dalam Mathematics Learning in Early Chilhood (Christoper, dkk, 2009, hlm. 24) angka menerangkan mengenai "jumlah" atau "banyak". Dengan kata lain, angka menerangkan berapa jumlah sesuatu atau berapa banyak sesuatu kumpulan.

Anak dapat mengembangkan suatu konsep ketika mereka mampu memasangkan dan menghubungkan bilangan dengan benda. Pembelajaran pemahaman konsep bilangan merupakan penanaman konsep dasar yang dapat menjadi jembatan yang dapat menghubungkan pola pikir anak yang masih bersifat konkrit ke abstrak. Begitu pula pemahaman konsep satu ke satu korespondensi, anak dapat mengerti bilangan dua merupakan dari dua buah benda. Materi tersebut terdapat dalam pedoman pengembangan program pembelajaran di Taman Kanak-kanak dalam Kurikulum Taman Kanak-kanak Tahun 2010 untuk anak TK pada Kelompok A (usia 4-5 tahun). 
Anak-anak dikatakan telah memahami konsep bilangan saat mereka telah mampu menghitung jumlah benda dan menuliskannya dengan simbol serta mampu menentukan jumlah benda "lebih sedikit", "sama" dan "lebih banyak".

Hurlock dalam Ahmad (2011,h.2) memahami konsep bilangan melalui permainan sangat penting karena dengan permainan anak dapat cepat maksud dari pembelajaran tersebut. Penulis membuat enam tahapan, dimana tahapan ini saling berkaitan dan mempengaruhi. Berdasarkan definisi operasional tentang kemampuan, konsep, bilangan dan karakteristik anak usia 4-5 tahun. Dapat kita simpulkan bahwa kemampuan mengenal konsep bilangan pada anak 4-5 tahun adalah potensi yang ada pada diri anak dan merupakan kesanggupan anak dalam mengenal suatu rancangan dalam bentuk angka yang dimulai dari angka 1,2,3,4,5 dan seterusnya yang berfungsi menentukan banyaknya suatu himpunan. Potensi ini bisa di asah atau distimulus, jadi setiap individu memiliki kemampuan yang berbeda-beda sesuia dengan pembiasaan dan latihan yang mereka lakukan .Maka adapun langkah - langkah nya adalah sebagai berikut:

\begin{tabular}{|c|l|l|}
\hline No & Langkah - Langkah Kegiatan & Target Pencapaian \\
\hline 1 & Membilang, berhitung 1-10 & Pemahaman konsep \\
2 & Mengurutkan angka 1-10 & bilangan \\
3 & Membandingkan lambang & \\
& bilangan & \\
\hline 4 & Menghubungkan/memasangkan & Pemahaman \\
& lambang bilangan dengan benda & lambang \\
5 & Menunjukan angka 1-10 & \\
\hline 6 & Meniru lambang bilangan & \\
\hline
\end{tabular}

Sumpit angkasa adalah media pembelajaran yang berbahan dasar sumpit yang dikreasikan dengan bentuk-bentuk benda luar angkasa seperti Bulan, bintang, matahari dan awan. Media ini dibuat untuk membuat pembelajarana mengenal konsep bilangan anak usia dini. Media ini dilengkapi dengan kartu angka dan konsep bilangan lainnya. Menurut Arsyad (2009:108) media visual merupakan suatu bentuk menyeluruh yang dapat dilihat yang dapat membantu pemahaman pesan atau informasi yang 
dikandungnya. Dengan sumpit angkasa penulis berharap dapat merubah pembelajaran yang menjenuhkan menjadi menyenangkan, sumpit ini beraneka warna sehingga dapat menarik minat anak untuk memainkannya.

\section{Metode}

Metode yang digunakan dalam penelitian ini yaitu Metode Penelitian Tindakan Kelas (PTK). Desain penelitian yang digunakan adalah model penelitian Kurt Lewin. Alasan peneliti menggunakan desain ini karena permasalahan tentang rendahnya pemahaman konsep bilangan beserta lambang bilangan merupakan suatu permasalahan yang terjadi dalam proses pembelajaran di kelas, dan permasalahan tersebut dapat dilakukan perbaikan melalui berbagai tindakan- tindakan tertentu supaya anak mendapatkan konsep yang bermakna dan mencapai titik pemahaman. Selain itu, desain penelitian ini sering digunakan didunia pendidikan hal tersebut dikarenakan dalam satu siklus terdiri dari empat langkah, yaitu: (1) Perencanaan (Planning), (2) Tindakan (Acting), (3) Pengamatan (Observing), (4) Refleksi (Reflecting). Oleh karena itu, model penelitian tindakan kelas yang cocok digunakan dalam hal ini yaitu Kurt Lewin karena dapat dilakukan secara berkesinambungan .

\section{Hasil dan Pembahasan}

Penelitian tindakan kelas anak usia 4-5 tahun di TK Khoirunnisa Kecamatan Cikupa Kabupaten Tangerang yang bertujuan untuk meningkatkan kemampuan mengenal konsep bilangan melalui media sumpit angkasa dilaksanakan dalam 3 siklus.

Berdasarkan data observasi awal yang telah dilakukan peneliti di TK Khoirunnisa Kecamatan Cikupa Kabupaten Tangerang, kondisi awal pada kemampuan mengenal konsep bilangan pada anak usia 4-5 tahun terlihat masih rendah. Karena 6 indikator pengenalan konsep bilangan yang harusnya dapat dicapai, 


\section{Siklus I}
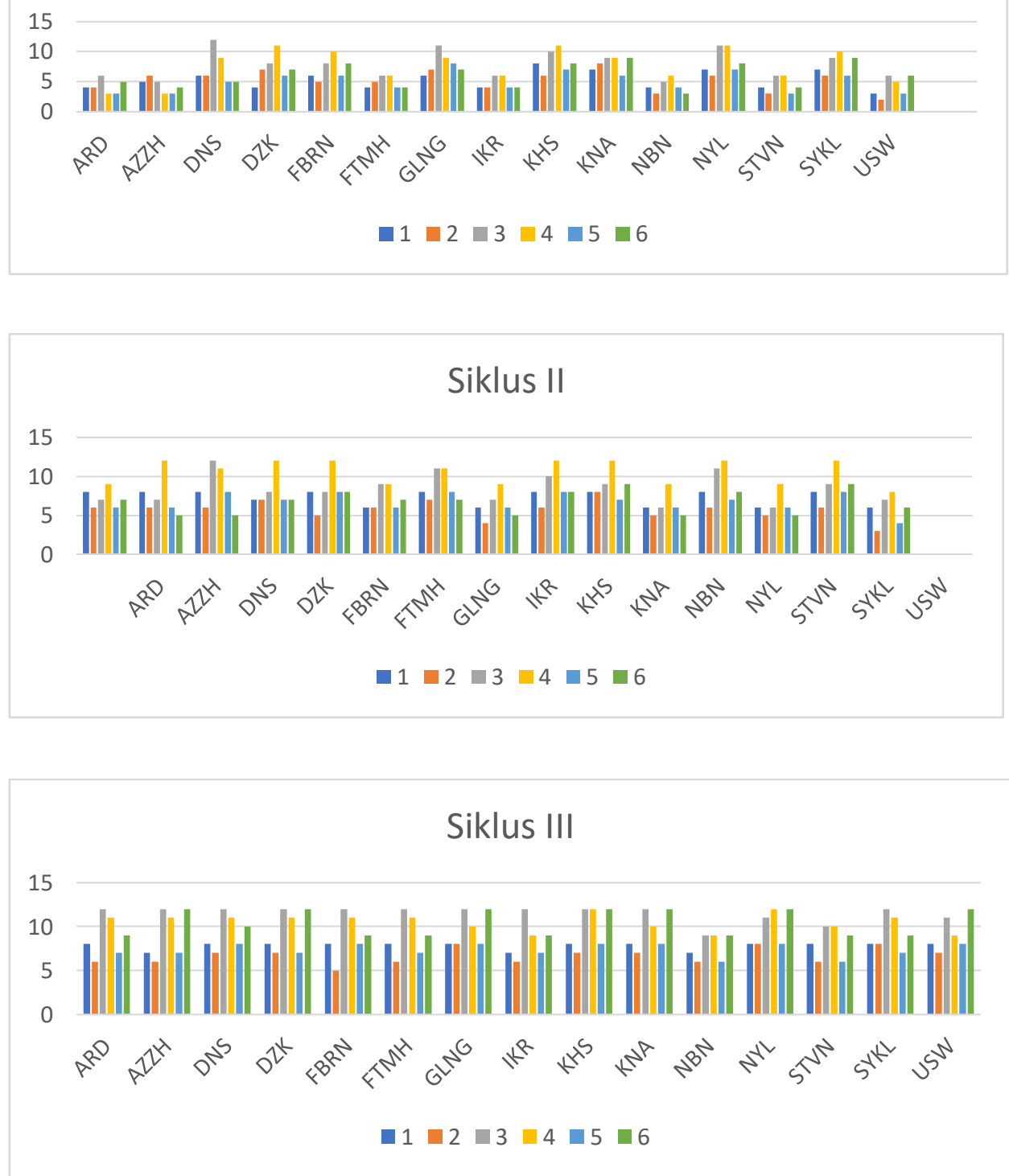

Berdasarkan hasil penelitian tentang meningkatkan kemampuan mengenal konsep bilangan pada anak usia 4-5 tahun yang telah dilakukan di TK Khoirunnisa Kecamatan Cikupa Kabupaten Tangerang maka dapat disimpulkan bahwa media sumpit angkasa dapat meningkatkan kemampuan mengenal konsep bilangan. Hal ini dapat dilihat pada saat kondisi awal yang mampu mengenal konsep bilangan masih rendah yaitu sebanyak 5 anak. Setelah melakukan tindakan dengan mengenal konsep bilangan melalui media sumpit angkasa meningkat menjadi sebanyak 9 anak . Pada siklus I yang mencapai indikator keberhasilan sebanyak 8 anak, Siklus II sebanyak 11 anak dan pada siklus III sebanyak 14 anak yang mampu mencapai 
indikator keberhasilan. Adapun pada siklus I terjadi peningkatan pada anak sebesar 53\%. Anak mulai dapat membilang, menunjukan lambang bilangan dan menghubungkan lambang bilangan dengan media sumpit angkasa, mengenal konsep lebih banyak dan lebih sedikit, mengurutkan angka serta mampu menirukan lambang bilangan. Pada siklus II adanya peningkatan sebesar $73 \%$ dan pada siklus III mengalami peningkatan sebesar $93 \%$.

\section{Kesimpulan}

Berdasarkan hasil penelitian maka dapat disimpukan bahwa pada siklus I terjadi peningkatan pada anak sebesar 53\%, siklus II peningkatan sebesar $73 \%$ dan pada siklus III mengalami peningkatan sebesar 93\% anak dapat sesuai harapan membilang, menunjukan lambang bilangan, menghubungkan lambang bilangan, mengenal konsep lebih banyak-sedikit, mengurutkan angka serta menirukan lambang bilangan melalui media sumpit angkasa. Dengan adanya media sumpit angkasa dapat meningkatkan kemampuan bilangan anak usia dini.

\section{Daftar Pustaka}

Arsyad, Azhar. (2017). Media Pembelajaran. Jakarta : Rajawali Pers

Rachmi, Titi. (2017). Konsep Dasar PAUD. Tangerang: Wade Grup.

Mulyasa, E. (2017). Praktik Penelitian Tindakan Kelas. Bandung : PT Remaja Rosda Karya.

Santrock, John W. (2011). Masa Perkembangan Anak. Jakarta: Salemba Humanika.

Sujiono, Yuliani dkk. (2018). Metode Pengembangan Kognitif. Tangerang Selatan: Universitas Terbuka.

Hildayani, Rini dkk. (2018). Psikologi Perkembangan Anak. Tangerang Selatan: Universitas Terbuka.

Gunarti, Winda dkk. (2018). Metode Pengembangan Perilaku dan Kemampuan Dasar Anak Usia Dini. Tangerang Selatan : Universitas Terbuka.

Zaman, Badru dan Asep Hery. (2016). Media dan Sumber Belajar PAUD. Tangerang selatan : Universitas Terbuka.

Sugiyono. (2016). Metode Penelitian Pendidikan. Bandung : ALFABETA

Widoyoko Putro (2016). Tehnik Penyusunan Istrumen Penelitian. Yogyakarta : PUSTAKA BELAJAR. 
Jurnal Program Studi Pendidikan Anak Usia Dini

"Ceria"

Undang-Undang Dasar No.20 Tahun 2003

Jurnal Pendidikan Anak Usia Dini Vol 2, no 1,2019, 11-17.

Jurnal Pendidikan Anak Usia Dini Vol 1, no 2, 2019, hlm. 86 - 94

Mulyasa. (2017) Praktik Penelitian Tindakan Kelas. Bandung : PT Remaja Rosdakarya 